\title{
CT parameter change and radiation dose effect for metastatic patients treated with palliative radiotherapy
}

\section{Palyatif radyoterapi uygulanan metastatik hastalarda BT parametre değişikliği ve radyasyon dozuna etkisi}

\section{Serdar Savaş Gü̈l${ }^{1}$, Güner İpek Arslan Kabalay ${ }^{2}$, Gülhan Güler Avcı ${ }^{1}$, Yasin Çoban ${ }^{1}$, Adil Merih ${ }^{1}$, Tuğba Güill ${ }^{3}$, Serkan Güirguiil ${ }^{4}$}

Gaziosmanpașa University, Faculty of Medicine, Department of Nuclear Medicine, Tokat.

${ }^{2}$ Turkish Health Ministry, Union of Public Hospitals, Department of Radiation Oncology, Istanbul.

3 Turkish Health Ministry, Turkish Public Health Establishment, Ankara.

${ }^{4}$ Gaziantep University, Faculty of Medicine, Department of Biophysics, Gaziantep.

Corresponding author:Serdar Savaş Gül, Gaziosmanpaşa University, Faculty of Medicine, Department of Nuclear Medicine, Tokat,

E-mail:gopnukleertip@gmail.com

Received/Accepted:September 08, 2017 / January 11, 2018

Conflict of interest: There is not a conflict of interest.

\begin{abstract}
SUMMARY
Objective: The aim of the present study was to determine the methods to reduce the radiation dose during imaging carried out for patients with bone or other organ metastases who were treated with palliative radiotherapy. In planning stages of treatment for these patients, tomographic imaging with computed tomography (CT) is performed on affected area using three-dimensional (3D) conformal radiotherapy. To what level the radiation dose could be lowered in imaging was investigated via changing the parameters used in CT scanning.
\end{abstract}

Method: Twenty seven patients with metastases treated in the Radiation Oncology department (16M, 11F, mean age 65.2 \pm 11.9 years) were included in the study. These patients underwent a total of 30 palliative radiotherapy treatments. Standard CT dose of 72 milli-ampere-second (mAs) and 130 peak kilo voltage $(\mathrm{kVp})$ in CT 1 scanning carried out for radiotherapy planning was lowered to $30 \mathrm{mAs}$ and $130 \mathrm{kVp}$ in CT 2 scanning.

Results: Radiation dose was reduced by $62.68 \% \pm 0.02$ percent as a result of changes made in planning CT scan $(\mathrm{p}<0.0001)$. Analysis of the images obtained revealed that despite the minimal reduction in image quality, results had no effect on treatment planning.

Conclusions: It was concluded that the radiation dose could be reduced via making changes in the parameters of CT scanning during palliative radiotherapy planning stage.

Keywords: Palliative radiotherapy, computed tomography, radiation management

ÖZET

Amaç: Bu çalışmanın amacı kemik ve diğer organ metastazı bulunan ve palyatif radyoterapi uygulanan hastalarda görüntüleme esnasında radyasyon dozunu azaltma yöntemlerini ortaya koymaktır. Metastazı bulunan hastalarda üç boyutlu (3D) konformal radyoterapi planlama aşamasında, ilgili bölgenin Bilgisayarlı tomografi (BT) ile tomografik görüntülemesi yapılmaktadır. BT çekimi için kullanılan parametrelerde değişiklik yapılarak, görüntüleme aşamasında radyasyon dozunun ne kadar azaltılabileceği araştırıldı.

Yöntem: Radyasyon Onkolojisi bölümünde tedavi edilen metastazı olan 27 hasta (16E, 11K, yaş ortalaması 65.2 yıl \pm 11.9) çalışmaya dahil edildi. 27 hastaya 30 palyatif radyoterapi uygulandı. Radyoterapi planlaması için yapılan 1. BT çekimde 72 mili-amper-saniye (mAs) ve 130 kilo-volt-pik (kVp) olan standart BT dozu 2. Çekimde 30mAs and $130 \mathrm{kVp}$ olacak şekilde değiştirildi. 
Bulgular: Planlama BT çekiminde yapılan değişiklik sonucunda radyasyon dozu $\% 62.68 \pm 0.02$ oranında azaltıldı $(p<0,0001)$. Elde edilen görüntüler incelendiğinde görüntü kalitesinde minimal azalma olmakla birlikte bunun tedavi planlamasını etkilemediği görüldü.

Sonuç: Çalışma sonucunda palyatif radyoterapi planlaması aşamasında BT cihazının parametrelerinde değişiklik yapılarak radyasyon dozunun azaltılabileceği düşünüldü.

Anahtar sözcükler: Palyatif radyoterapi, bilgisayarlı tomografi, radyasyon yönetimi

\section{INTRODUCTION}

Radiotherapy is a therapy method using ionizing radiation to shrink or destroy cancer cells. It is commonly used for the treatment of malign tumors and some benign tumors. The basic approach is to protect critical organs and tissues from side effects as much as possible while applying high rate of radiotherapy to tumor.

For radiotherapy methods, three-dimensional treatment planning is prepared using computed tomography (CT) and magnetic resonance imaging (MRI). Thus, target cancer volumes take the planned dose with high accuracy and surrounding normal tissues are protected at maximum level ${ }^{1}$. $\mathrm{CT}$ accounts for $5 \%$ of imaging methods using $\mathrm{X}$ rays and is commonly used in radiology practice ${ }^{2}$.

Based on radiological developments, new strategies are being developed to decrease radiation dose using appropriate parameters without deteriorating the image quality in $\mathrm{CT}^{3,4}$. The aim of the present study was to determine to what level the effective radiation exposed by the patients could be lowered via changing CT scanning parameters in metastatic patients treated with palliative treatment. We hope to show that reducing the radiation dose of metastatic patients with the principles of ALARA (As Low As Reasonably Achievable) in this study.

\section{MATERIAL AND METHODS}

Twenty seven patients (16 M, $11 \mathrm{~F}$, average age $65.2 \pm 11.9$ years) with metastasis having palliative radiotherapy in Radiation Oncology Department were included in the present study. Furthermore three patients had previous radiotherapies in different areas. In the first scanning which constituted the basis for the palliative radiotherapy planning of the patients, standard CT scanning parameters of 72 milli-amper-second (mAs) and 130 peak kilo voltage $(\mathrm{kVp})$ were used. Radiation dose exposed by the patients during CT scanning was calculated. Planning imaging of a patient who had palliative radiotherapy in thoracic region was given in figure 1.
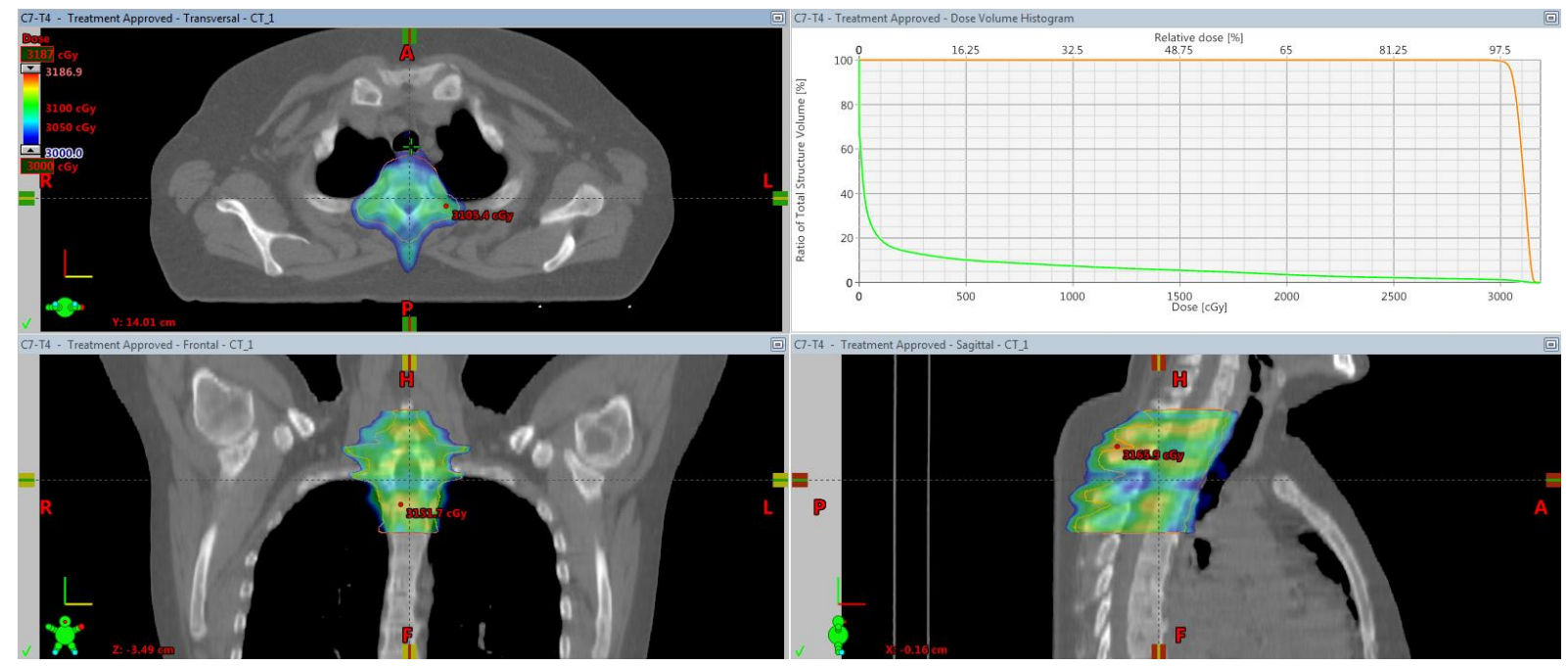

Figure 1. Planning images of patient whom palliative radiotherapy was planned in thoracic region.

For effective radiation dose measurement, Computed Tomography Dose Index (CTDI) was calculated. CTDI is calculated by dividing the integral (sum) of dose absorbed along with the longitudinal axis by nominal dissection thickness (s). Dose Length Product (DLP) is obtained by 
multiplying CTDIvol by scanning length (L). Conversion factor is used to calculate effective dose (ED) value for different manufacturers and different patient thicknesses. Effective dose is calculated by the following formulae:

"ED $(\mathrm{mSv} \times \mathrm{cm})=$ Conversion factor $\mathrm{x}$ DLP"
Statistical Iterative Reconstruction (IR) method, on the other hand, is based on lowering of noise using statistical methodsin images basically obtained by low $\mathrm{kV}$ and $\mathrm{mA}$ and high table feed and gantry rotation speeds ${ }^{5}$. Standard CT scanning parameters of the same patients were changed to $30 \mathrm{mAs} 130$ $\mathrm{kVp}$ at the start of the second radiotherapy session (Figure 2).

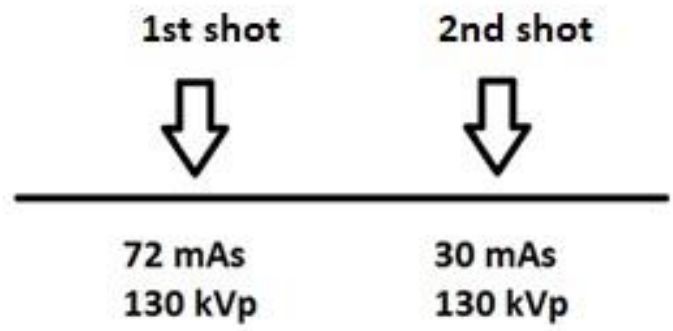

Figure 2. Changes in CT parameters in the first and second scanning for patients receiving palliative radiotherapy.

Radiation dose exposed during the CT scanning was calculated again. In addition, images obtained were studied and whether there were any differences in imaging quality was investigated.

Data obtained were compared using Paired Samples Test and Statistical Difference Test by SPSS 18.0 software. $\mathrm{P}<0.05$ was considered statistically significant. An Ethics Board approval was taken from Gaziosmanpaşa University Clinical Investigations Board for the present study.

\section{RESULTS}

Diagnoses of the patients included in the study were as follows: lung cancer (eight patients, $29.6 \%$ ), breast cancer (six patients, 22.2\%), multiple myeloma (three patients, $11.1 \%$ ), prostate cancer (two patients, 7.4\%), and stomach, pleural mesothelioma, cervix, renal cell, hepatocellular, ovarian, bladder and colorectal cancers (one patient each, 3.7\%). Locations of metastatic lesions, on the other hand, were axial skeleton (eighteen patients, $60 \%$ ), appendicular skeleton (six patients, 20\%) and cranium (six patients, 20\%).

Effective radiation dose exposed by the patients during standard CT scanning with $72 \mathrm{mAs} 130 \mathrm{kVp}$ parameters was calculated as milisievert (mSv). Standard CT scanning parameters were changed to $30 \mathrm{mAs} 130 \mathrm{kVp}$ in the second session of scanning of the same patients, and effective radiation dose exposed was calculated again as $\mathrm{mSv}$. Demographic data of the patients and radiation level exposed by them during CT scanning were given in Table 1.

Table 1. Demographic data of patients and effective dose values exposed by patients in the first scanning with the parameters of $72 \mathrm{mAs} 130 \mathrm{kVp}$ and in the second scanning with the parameters of $30 \mathrm{mAs} 130 \mathrm{kVp}$.

\begin{tabular}{lccccc}
\hline Lesion Localization & $\begin{array}{c}\text { Number of } \\
\text { Applications }\end{array}$ & $\begin{array}{c}\text { Scanning } \\
\text { Length (cm) }\end{array}$ & $\begin{array}{c}\mathbf{1}^{\text {st }} \text { Scanning } \\
(\mathbf{m S v})\end{array}$ & $\begin{array}{c}\mathbf{2}^{\text {nd }} \text { Scanning } \\
(\mathbf{m S v})\end{array}$ & Difference \% \\
\hline Whole brain & 6 & $29.8 \pm 4.1$ & $33.9 \pm 4.7$ & $12.7 \pm 1.7$ & 62.7 \\
Cervical Vertebrae & 2 & $42.6 \pm 3.8$ & $48.6 \pm 4.3$ & $18.1 \pm 1.5$ & 62.7 \\
Thoracic Vertebrae & 9 & $44.1 \pm 8.9$ & $50.2 \pm 10.2$ & $18.7 \pm 3.8$ & 62.7 \\
Lumbar Vertebrae & 9 & $48.4 \pm 6.1$ & $55.0 \pm 7.1$ & $20.5 \pm 2.6$ & 62.7 \\
Pelvis & 4 & $56.2 \pm 5.2$ & $63.9 \pm 5.9$ & $23.9 \pm 2.2$ & 62.7 \\
\hline
\end{tabular}


Comparative effective radiation levels exposed by the patients due to scanning were illustrated in figure 3 .

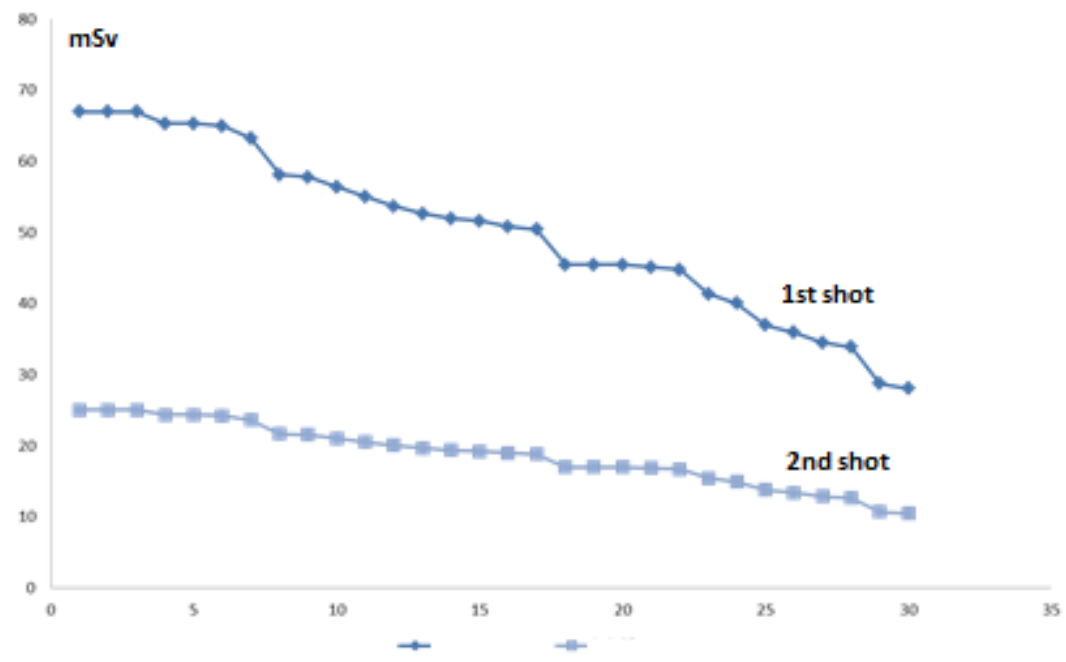

Figure 3. Comparison of effective dose levels exposed by patients in the first and second scanning.

Radiation level exposed by our patients using the second scanning parameters was decreased by $62.68 \pm 0.02 \%$ and this change was statistically significant $(\mathrm{p}<0.0001)$ (Figure 4).

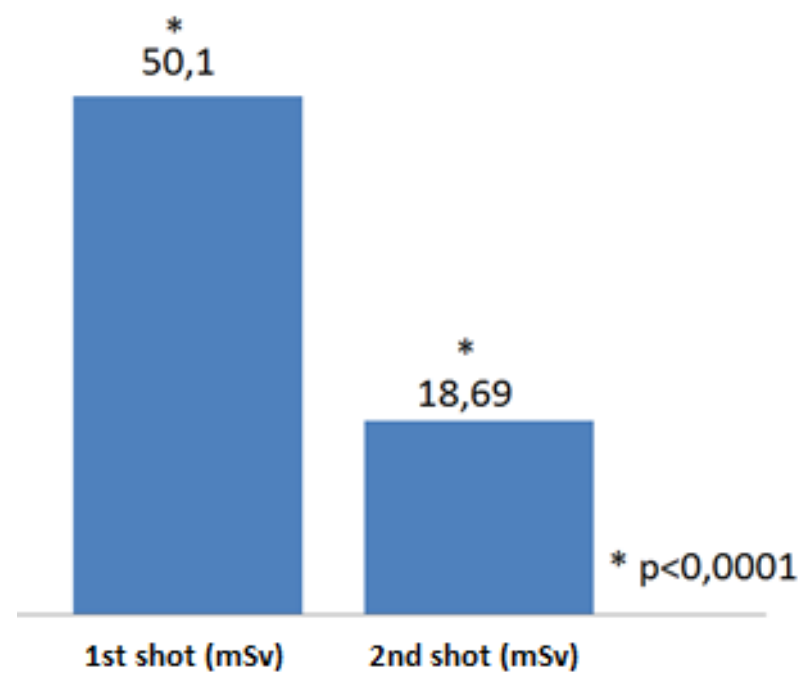

Figure 4. Radiation dose exposed by patients in the first (standard parameters) and second scanning (changed parameters) during planning CT.

In addition, images of the first and second CT scanning were evaluated visually in terms of lesion localization. CT scanning samples of our patients were shown in figure 5. 


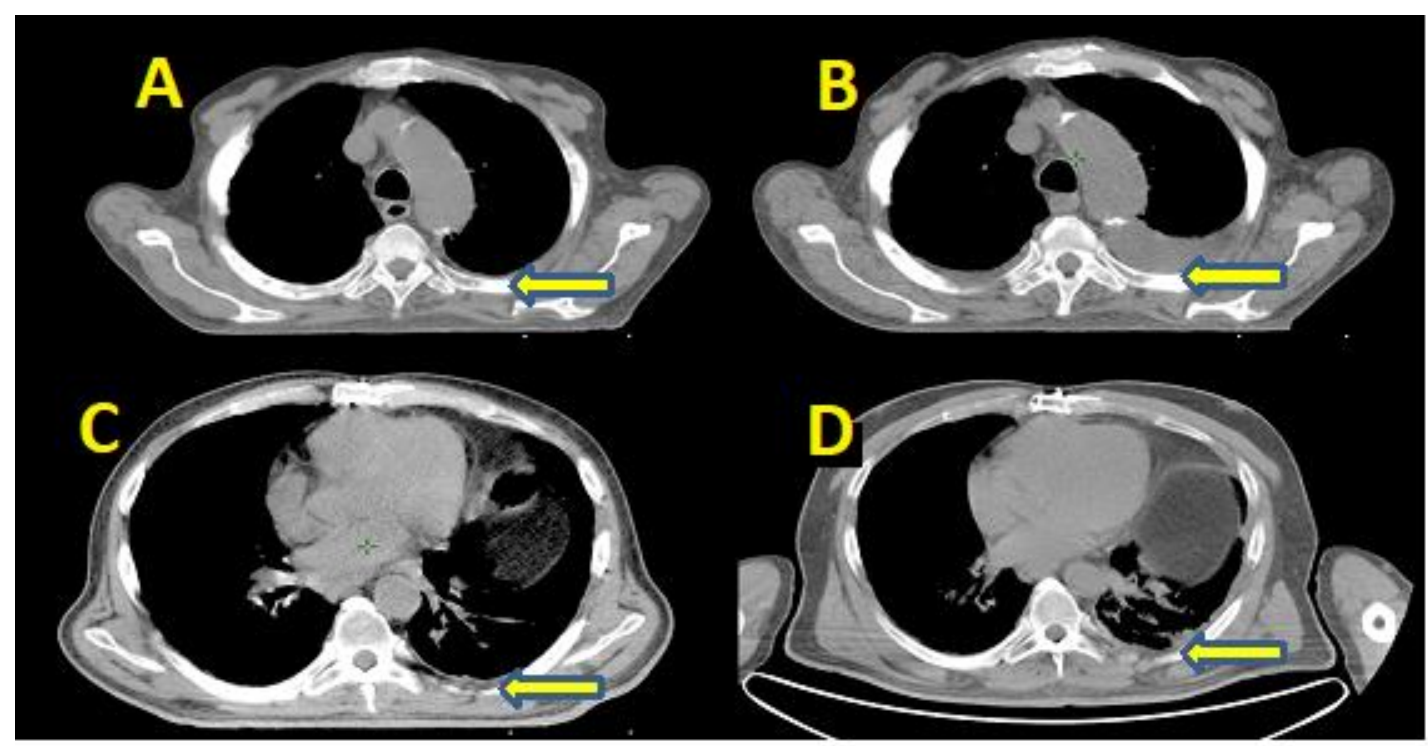

Figure 5. CT images of a patient having palliative radiotherapy in the first scanning using $72 \mathrm{mAs} 130 \mathrm{kVp}$ dose (A and C) and in the second scanning using $30 \mathrm{mAs} 130 \mathrm{kVp}$ dose (B and D). Lesions in transaxial slices were shown by arrows.

\section{DISCUSSION}

In the absence of an efficient radiotherapy planning, sufficient tumor treatment cannot be achieved, and early and late term side effects could be seen in normal tissue. Therefore, anatomic scanning methods such as CT and MRI are frequently used for radiotherapy planning ${ }^{6}$. Especially CT technology is essential in radiotherapy treatment planning systems. Use of CT technology has been common especially after the advent of spiral CT and multi-slice CT techniques ${ }^{7}$. In the present study, CT was used in 3D conformal radiotherapy planning for metastatic patients for whom palliative radiotherapy was suggested.

Increased cumulative radiation exposure has become a major health issue after the introduction of CT technology ${ }^{3,8}$. A survey revealed that $30 \%$ of the society had at least three CT examinations throughout their lives ${ }^{9}$. As in the present study, palliative radiotherapy patients take repeating radiotherapy sessions. Unfortunately, lowering the radiotherapy dose is not an option because it could prevent delivery of an efficient dose to cancerous tissue of patient. Therefore, we aimed to show the effect of lower planning $\mathrm{CT}$ radiation dose before treatment.

Higher level of radiation used during CT examination increases signal noise ratio, resulting in better images. However, it also leads to higher amount of exposure by patients. Studies to lower radiation level reported that acceptable dose limit of cumulative radiation which has the risk of causing cancer is $100 \mathrm{mSv}{ }^{10}$. Pitch of $\mathrm{X}$-ray tube and detector number were also reported to increase radiation amount. It has been shown that average effective radiation dose is $7.4 \mathrm{mSv}$ in single slice spiral CT and $8.1 \mathrm{mSv}$ in four-detector CT ${ }^{11}$. Weight-dependent study protocols are available for spiral CT ${ }^{12}$.

Parameters employed for reducing CT dose are number of slices going through the region to be studied, slice width, entrance speed of patient into gantry (table feed speed), rotation speed of gantry, kilo voltage and tube current. The most commonly used parameter to reduce radiation exposure is tube current. Tube current specifies number of photons coming from X-ray tube. Multiplying gantry rotation time (as full rotation, second) by number of photons give mAs, which is the unit considered. While higher tube current results in poorer image quality in direct radiography, it leads to better image quality but also causes higher radiation exposure in CT. Lower tube current, on the hand, causes lower signal noise ratio, spatial resolution and image quality. In general, when the tube current is lowered by $50 \%$, amount of radiation exposure also drops by $50 \%$. Similarly, shortening of gantry rotation time from one second to half a second lowers the amount of exposure to $50 \%$. Studies about lowering the radiation exposure reported that head-neck, thorax, abdomen and pelvis could be studied using lower tube current without any major loss of image quality ${ }^{13,14}$. Lower mAs use has been suggested especially for thorax CT examination because number of solid organs through which X-ray photons pass is fewer 
in thoracic region ${ }^{12}$. In the present study, CT scanning was carried out using lower mAs levels in an effort to decrease radiation exposure by patients.

In CT examination for radiotherapy planning for oncology patients with bone metastasis, adjustment of technical parameters based on ALARA principles is crucial to lower the exposure to radiation ${ }^{15}$. In accordance with these principles, the present study aimed to lower CT radiation dose.

Although various parameters have been suggested to measure the radiation exposure by patients, the most commonly used parameter in daily practice for this purpose is effective dose, whose unit is $\mathrm{mSv}$, because it allows comparison of radiation exposure caused by different methods ${ }^{16}$. Therefore, we employed $\mathrm{mSv}$ as effective dose measurement method in the present study and were able to calculate dose values of CT scanning using standard and modified parameters.

\section{CONCLUSION}

Cancer patients with metastasis are subjected to repetitive examinations involving radiation for both diagnosis and treatment purposes. CT has an important place among diagnostic examinations. Results of the present study suggested that during 3D conformal radiotherapy planning process in patients with metastasis, CT parameters could be changed and radiation level exposed by patients could be lowered without resulting in any major loss of image quality of CT examination. This method of making changes in the CT parameters can also be used in patients receiving curative radiotherapy.

\section{REFERENCES}

1- Vernon MR, Maheshwari M, Schultz CJ, Michel MA, Wong SJ, Campbell BH, et al. Clinical outcomes of patients receiving integrated PET/CT-guided radiotherapy for head and neck carcinoma. Int J Radiat Oncol Biol Phys 2008; 70: 678-84.

2- Ron E. Ionizing radiation and cancer risks: evidence from epidemiology. Pediatr Radiol 2002; 32: 232-7.

3- Kalra MK, Maher MM, Toth TL, Hamberg LM, Blake MA, Shepard JA, et al. Strategies for CT radiation dose optimization. Radiology 2004; 230: 619-28.

4- McCollough $\mathrm{CH}$, Primak AN, Braun N, Kofler J, Yu L, Christner J. Strategies for Reducing Radiation Dose in CT. Radiol Clin North Am 2009; 47: 27-40.
5- Sağsöz ME, Alper F. Kardiyak Multi Dedektör Bilgisayarlı Tomografide (MDBT) Radyasyon Dozu. TRD Sem 2013; 1: 16-25.

6- International Commission on Radiation Units and Measurements (ICRU), Prescribing, Recording and Reporting Photon Beam Therapy (Report 50).

7- Berland LL, Smith JK. Multidetector-array CT: once again, technology creates new opportunities. Radiology 1998; 209: 327-9.

8- Golding SJ, Shrimpton PC. Radiation dose in CT: are we meeting the challenge? Br J Radiol 2002; 75: 1-4.

9- Brenner DJ. Estimating cancer risks from pediatric CT: going from the qualitative to the quantitative. Pediatr Radiol 2002; 32: 228-33.

10- Strom DJ, Cameron JR. Is it useful to assess annual effective doses that are less than 100 mSv? Radiat Prot Dosimetry 2002; 98: 239-45.

11- Brix G, Nagel HD, Stamm G, Veit R, Lechel $\mathrm{U}$, Griebel J, et al. Radiation exposure in multislice versus single-slice spiral CT: results of a nationwide survey. Eur Radiol 2003; 13: 197991.

12- Donnelly LF, Emery KH, Brody AS, Laor T, Gylys-Morin VM, Anton CG, et al. Minimizing radiation dose for pediatric body applications of single detector helical CT. Am J Roentgenol 2001; 176: 303-6.

13- Zhu X, Yu J, Huang Z. Low-dose chest CT: optimizing radiation protection for patients. Am J Roentgenol 2004; 183: 809-16.

14- Hagtvedt $T$, Aalokken TM, Notthellen $J$, Kolbenstvedt A. A new low-dose CT examination compared with standard-dose CT in the diagnosis of acute sinusitis. Eur Radiol 2003; 13: 976-80.

15- Strauss KJ, Kaste SC. The ALARA (As Low As Reasonably Achievable) Concept in Pediatric Interventional and Fluoroscopic Imaging: Striving to Keep Radiation Doses as Low as Possible during Fluoroscopy of Pediatric Patients A White Paper Executive Summary Radiology 2006; 240: 621-2.

16- Shapiro BP, Young PM, Kantor B, Choe YH, McCollough $\mathrm{CH}$, Gerber TC. Radiation dose reduction in CT coronary angiography. Curr Cardiol Rep 2010; 12: 59-67. 